\title{
A20 deubiquitinase controls PGC-1a expression in the adipose tissue
}

\author{
Bruna Bombassaro ${ }^{1}$, Leticia M. Ignacio-Souza', Carla E. Nunez', Daniela S. Razolli', Rafael M. Pedro', \\ Andressa Coope ${ }^{1}$, Eliana P. Araujo ${ }^{1}$, Elinton A. Chaim² and Licio A. Velloso ${ }^{1,3^{*}}$ (i)
}

\begin{abstract}
Background: Peroxisome proliferator-activated receptor $y$ coactivator- 1alpha (PGC-1a) plays an important role in whole body metabolism and, particularly in glucose homeostasis. Its expression is highly regulated and, small variations in tissue levels can have a major impact in a number of physiological and pathological conditions. Recent studies have shown that the ubiquitin/proteasome system plays a role in the control of PGC-1a degradation.

Methods: Here we evaluated the interaction of PGC-1a with the protein A20, which plays a dual-role in the control of the ubiquitin/proteasome system acting as a deubiquitinase and as an E3 ligase. We employed immunoprecipitation, quantitative real-time PCR and immunofluorescence staining to evaluate PGC-1a, A20, PPARY and ubiquitin in the adipose tissue of humans and mice.

Results: In distinct sites of the adipose tissue, A20 binds to PGC-1a. At least in the subcutaneous fat of humans and mice the levels of PGC-1a decrease during obesity, while its physical association with A20 increases. The inhibition of A20 leads to a reduction of PGC-1a and PPARY expression, suggesting that A20 acts as a protective factor against PGC-1 a disposal.
\end{abstract}

Conclusion: We provide evidence that mechanisms regulating PGC-1a ubiquitination are potentially involved in the control of the function of this transcriptional co-activator.

Keywords: Fat, Ubiquitination, Glucose, Diet, Obesity

\section{Background}

Peroxisome proliferator-activated receptor $\gamma$ coactivator 1 alpha $(\mathrm{PGC}-1 \alpha)$ is a co-activator of transcription involved in the control of a number of metabolic functions in a diversity of tissues in mammals [1, 2]. It was first identified in brown adipose tissue (BAT) due to its important role in the modulation of peroxisome proliferator-activated Receptor gamma (PPAR $\gamma$ ) - dependent uncoupling protein-1 (UCP1) expression [3, 4]. Because of its pleotropic functions, the regulation of PGC- $1 \alpha$ expression by extracellular signals is complex and varies in distinct tissues. Thus, for example, in BAT and pancreatic islets it is induced by cold [3-6], in skeletal muscle it is induced by exercise [7, 8], and in the liver it is induced by fasting [9]. In

\footnotetext{
* Correspondence: lavelloso.unicamp@gmail.com

${ }^{1}$ Laboratory of Cell Signaling, Obesity and Comorbidities Research Center

University of Campinas, Campinas, Brazil

${ }^{3}$ Laboratory of Cell Signaling, Faculdade de Ciencias Medicas da

Universidade Estadual de Campinas, Campinas, SP 13084 970, Brazil

Full list of author information is available at the end of the article
}

addition, at the intracellular level, PGC-1 $\alpha$ gene expression can be controlled by many different mechanisms, such as cyclic AMP and $\mathrm{Ca}^{+2}$ signaling through cyclic AMP response element-binding protein (CREB) $[10,11]$, NOinduced cyclic GMP pathway [12], myocyte enhancer factor (MEF), and even through an auto-regulatory loop in white adipose tissue (WAT) leading to PPAR $\gamma$ activation [13].

The availability of PGC- $1 \alpha$ in a given cell impacts on the immediate regulation of target gene transcription, which means that both production, i.e., transcription and translation, and degradation of PGC- $1 \alpha$ must be tightly controlled [1]. If in one hand the control of PGC$1 \alpha$ production has been widely studied, on the other hand, little is known about the processes and mechanisms that lead to its degradation. Under physiological conditions the half-life of PGC- $1 \alpha$ is as short as $2-3 \mathrm{~h}$ [14]. However, this can be modulated by different intracellular signals such as p38 mitogen-activated protein kinases (MAPK) and p160 myb [14, 15]. Also, recent

(C) The Author(s). 2018 Open Access This article is distributed under the terms of the Creative Commons Attribution 4.0 International License (http://creativecommons.org/licenses/by/4.0/), which permits unrestricted use, distribution, and 
studies have shown that PGC-1 $\alpha$ is degraded through the ubiquitin-proteasome system $[16,17]$.

The ubiquitination of target proteins plays an important and wide-ranging role in the homeostasis of cells. Typically it targets damaged proteins to proteasome degradation $[18,19]$ and potentially detrimental protein aggregates that cannot be degraded by the proteasome, to autophagy [20, 21]. There are a number of steps and mechanisms involved in the activation and control of the ubiquitination machinery [18]. One of such regulatory events is carried out by a family of proteins with deubiquitinase activity [18]. Interestingly, deubiquitination of target proteins plays an important role in the control of inflammatory signaling pathways, particularly by the action of A20 deubiquitinase through the regulation of nuclear factor-kappaB (NFKB) activity [21, 22].

In obesity, the hypertrophic WAT is targeted by a low-grade inflammatory process on which the activation of signaling through $\mathrm{NFKB}$ plays an important role [23]. An important outcome of this inflammatory process is the induction of insulin resistance and disruption of metabolic pathways [23]. Defective signaling though PPAR $\gamma$ plays an important role in adipose tissue insulin resistance and, the use of thiazolidinediones can greatly improve this phenotype [24]. It has been shown that PGC-1 $\alpha$ expression is greatly reduced in WAT of obese subjects. Therefore, we hypothesized that changes in ubiquitination, potentially involving the activity of A20, could explain at least part of the changes in WAT PGC-1 $\alpha$ expression. To test this hypothesis we evaluated PGC- $1 \alpha$ and A20 expression and PGC- $1 \alpha$ ubiquitination in the WAT of obese humans before and after body mass reduction resulting from bariatric surgery. In addition, we evaluated the same proteins and the effect of an oligonucleotide antisense (ASO) inhibition of A20 in the adipose tissue of an animal model of obesity. As a whole, our results show that PGC- $1 \alpha$ expression is reduced in obesity and its association with A20 is a protective factor against this reduction. When the expression of A20 is reduced by ASO the levels of PGC- $1 \alpha$ decrease and the animals become glucose intolerant.

\section{Methods \\ Experimental animals}

Six-week old male Swiss mice were fed on standard rodent chow or on a high-fat diet for 16 weeks. The macronutrient composition of diets is presented in Table 1. All experimental procedures were performed in accordance with the guidelines of the Brazilian College for Animal Experimentation and were approved by the University of Campinas Ethics Committee (\#CEUA 2216-1).
Table 1 Composition of the diets

\begin{tabular}{lll}
\hline & Diets & \\
\cline { 2 - 3 } & Chow & High-fat \\
\hline Protein (g\%) & 22.5 & 26 \\
Fat $(\mathrm{g} \%)$ & 4.5 & 35 \\
Carbohydrate $(\mathrm{g} \%)$ & 55 & 26 \\
Fiber (g\%) & 8 & 6 \\
Ash (g\%) & 10 & 7 \\
Total & 100 & 100 \\
Energy value $(\mathrm{kCal} / \mathrm{g})$ & 3.5 & 5.2 \\
\hline
\end{tabular}

\section{Human adipose tissue}

Subcutaneous adipose tissue from the abdominal wall was collected from 12 obese subjects during a Roux-in-Y gastric bypass surgery at the Clinics Hospital of the University of Campinas. The adipose tissue from nine lean volunteers was collected at the Laboratory of Investigation in Metabolism and Diabetes, University of Campinas. The exclusion criteria were, as follows: inflammatory or infectious disease acute or chronic, neurological disease, psychiatric illness, smoking, alcohol consumption greater than or equal to $30 \mathrm{~g}$ per day for men and $15 \mathrm{~g}$ per day for women, use of illicit drug, use of NSAIDs or corticosteroids, cancer, pregnancy, liver enzyme levels $>3$-times the upper limit of normal, chronic renal failure. Patients were informed about the project and signed a consent form. Volunteers could, at any time, withdraw from the project. The study was evaluated and approved by the University of Campinas Ethics Committee for Medical Research (\#833/2010).

\section{Antisense oligonucleotide (ASO) treatment}

An antisense oligonucleotide (ASO) targeting TNFAIP3 (gene coding for the A20 protein) and a scrambled ASO were designed and used to treat the experimental animals. The sequence of the TNFAIP3 ASO was 5'ACCCCAGTATTTGATCTTGT 3' and the scramble ASO was 5'TACTACGCGCATTCTTATTG 3' (Invitrogen, São Paulo, Brazil). The lyophilized ASOs were suspended in Tris-acetate-EDTA Buffer (40 mM Tris, $20 \mathrm{mM}$ acetic acid, $1 \mathrm{mM} \mathrm{EDTA}$ ) at $1 \mathrm{nmol} / \mu \mathrm{L}$ and diluted in saline for intraperitoneal injection, once a day for 7 days. This method was adapted from a previously published study [25].

\section{Intraperitoneal glucose tolerance test (ipGTT)}

Glucose was determined in blood using a glucometer from Abbott (Opptimum, Abbott Diabetes Care, Inc., Alameda, CA, USA). After an overnight fasting, the animals were fed during $1 \mathrm{~h}$ and then fasted for $4 \mathrm{~h}$. After the collection of the first blood sample (time 0), 20\% glucose $(2.0 \mathrm{~g} / \mathrm{kg}$ body weight) was administered via 
intraperitoneal injection. Blood samples from tails were collected at different times for the determination of glucose concentration.

\section{Immunoblotting}

The adipose tissue specimens were homogenized in a tissue homogenizer (Polytron-Aggregate, Kinematica, Littau/Luzern, Switzerland) at maximum speed in an anti-protease cocktail $(10 \mathrm{mmol} / \mathrm{L}$ imidazole, $\mathrm{pH}$ 8.0, $4 \mathrm{mmol} / \mathrm{L}$ EDTA, $1 \mathrm{mmol} / \mathrm{L}$, aprotinin, $2.5 \mathrm{mg} / \mathrm{L}$ leupeptin, $30 \mathrm{mg} / \mathrm{L}$ trypsin inhibitor, $200 \mu \mathrm{mol} / \mathrm{L}$ DTT and $200 \mu \mathrm{mol} / \mathrm{L}$ phenylmethylsulfonyl fluoride). After sonication, an aliquot of the extracts was collected and the total protein content was determined by the dye-binding protein assay kit (Bio-Rad Laboratories, Hercules, CA). Samples containing $100 \mu \mathrm{g}$ of protein were incubated for 5 min at $95{ }^{\circ} \mathrm{C}$ with $4 \times$ concentrated Laemmli sample buffer $(1 \mathrm{mmol}$ sodium phosphate/L, $\mathrm{pH} 7.8,0.1 \%$ bromophenol blue, 50\% glycerol, $10 \%$ SDS, $2 \%$ mercaptoethanol) or immunoprecipitated (500 $\mu \mathrm{g}$ of protein) with anti-A20 or anti-PGC- $1 \alpha(4: 1, \mathrm{vol} / \mathrm{vol})$ and then run on $10 \%$ polyacrylamide gels during approximately $4 \mathrm{~h}$. The amounts of antibodies used in the immunoprecipitation assays were sufficient to immunodeplete the samples as evaluated by running an immunoblotting assay of the supernatants. Electrotransfer of proteins to nitrocellulose membranes (Bio-Rad) was performed in a Trans Blot SD Semi-Dry Transfer Cell (Bio-Rad) for $1 \mathrm{~h}$ at $15 \mathrm{~V}$ (constant) in buffer containing methanol and SDS. After transfer, the membranes were blocked with $5 \%$ skimmed milk in Tween-/Tris-buffered saline (TTBS) $(10 \mathrm{mmolTris} / \mathrm{L}, 150 \mathrm{mmolNaCl} / \mathrm{L}$, and $0.5 \%$ Tween 20) overnight at $4{ }^{\circ} \mathrm{C}$. A20, PGC- $1 \alpha$ and ubiquitin were detected in the membranes after overnight incubation at $4{ }^{\circ} \mathrm{C}$ with primary antibodies (A20, sc166692; PGC-1 $\alpha$, sc13067, from Santa Cruz Biotechnology, Santa Cruz, CA and ubiquitin, ab7780 from AbCam, Cambridge, MA, USA; diluted 1:500 in TTBS containing 3\% dry skimmed milk). The membranes were then incubated with a secondary specific immunoglobulin $G$ antibody (diluted 1:5000 in TTBS containing 3\% dry skimmed milk) for $2 \mathrm{~h}$ at room temperature. Enhanced chemiluminescence (SuperSignal West Pico; Pierce) after incubation with a horseradish peroxidase-conjugated secondary antibody was used for detection by autoradiography. Band intensities were quantified by optical densitometry (UN-Scan-it Gel 6.1, Orem, Utah, USA).

\section{RNA extraction and real-time- $q P C R$}

The samples were homogenized in TRIzol reagent (Invitrogen, São Paulo, Brasil) in a tissue homogenizer (Polytron-Agregate, Kinematica, Littau/Luzern, Switzerland) at maximum speed. The total RNA content was then isolated according to the manufacturer's instructions, quantified and analyzed by spectrophotometry (NanoDrop 8000, Thermo Scientific, Wilmington, DE, USA). The integrity of RNA and the total amount were assessed by Nanodrop (Nanodrp 8000 Thermo Scientific). cDNA synthesis was performed in $3 \mu \mathrm{g}$ of total RNA, according the manufacturer's instructions (High Capacity cDNA Reverse Transcription Kit, Life Technologies, Van Allen Way Carlsbad, CA, USA). The TaqMan System was used in association with real-time PCR to detect A20 (TNFAIP3), PGC- $1 \alpha$ and PPAR $\gamma$ in the brown, visceral and subcutaneous adipose tissue (Mm00437121_m1; Mm44718 3 m1; Mm01184322_m1, respectively - Life Technologies, Van Allen Way Carlsbad, CA, USA) and the mouse GAPDH gene was used as an endogenous control (\#4352339E).

\section{Immunofluorescence staining}

For histological evaluation, brown and white adipose tissue samples were fixed in paraformaldehyde (4\% final concentration in phosphate-buffered saline [PBS; $50 \mathrm{mmol} / \mathrm{L}$ of $\mathrm{NaH} 2 \mathrm{PO} 4 \cdot \mathrm{H} 2 \mathrm{O} ; 5 \mathrm{mmol} / \mathrm{L}$ of $\mathrm{KCl} ; 1.5 \mathrm{mmol} / \mathrm{L}$ of $\mathrm{MgCl} 2 \cdot 6 \mathrm{H} 2 \mathrm{O}$; and $80.1 \mathrm{mmol} / \mathrm{L}$ of $\mathrm{NaCl} ; \mathrm{pH} 7.4])$ and processed routinely for embedding in a paraffin block. The samples were submitted to dehydration (alcohol at $70 \%, 80 \%, 90 \%, 95 \%$, and absolute alcohol) being diaphanized by immersion in xylol and embedded in paraffin. Subsequently, the hydrated (alcohol at absolute, 95, 90, 80, and $70 \%$ concentrations) 5.0 um paraffin sections were processed for immunofluorescence staining using the Ubiquitin, A20 and PGC-1 $\alpha$ antibodies (sc271289; sc166692, sc13067 respectively - Santa Cruz Biotechnology, Santa Cruz, CA) and the secondary antibodies conjugated to FITC or rhodamine (sc2777; sc2092, respectively - Santa Cruz Biotechnology, Santa Cruz, CA). The images were obtained using a Confocal Laser Microscopy (LSM510, Zeiss, New York, NY). Analyses of results were performed using a Leica Application Suite V3.6 (Switzerland).

\section{Statistical analysis}

Results are presented as means \pm SE. The homogeneity of variances was checked by Levene's test to verify if the data were parametric. When necessary, to correct for variance heterogeneity or non-normality, data were logtransformed [26]. The results were analyzed by Studenttest or One-way ANOVA and complemented by the Tukey test to determine the significance of individual differences. The level of significance was set at $p<0.05$. The data were analyzed using Statistic for Windows, 7.0 (StatSoft, Inc., Tulsa, OK, USA).

\section{Results}

PGC-1a and A20 are reduced in the adipose tissue of obese subjects

Except for body mass index, the groups of subjects presented no differences in age, glucose, HbA1c and 
cholesterol (Table 2). Nevertheless, the protein expressions of both PGC- $1 \alpha$ and A20 were significantly reduced as compared to control (Fig. 1a-c), while the associations of PGC- $1 \alpha$ with ubiquitin and A20 were increased (Fig. 1a, d and e).

\section{PGC-1a and A20 are differentially expressed in distinct sites and types of adipose tissue in mice}

Because of the differences in function and potential for inflammatory response presented by the distinct sites and types of adipose tissue, we evaluated the expressions of PGC- $1 \alpha$ and A20 in samples obtained from the brown adipose tissue and from either visceral or subcutaneous fat from lean and obese mice. As depicted in Fig. 2a-d, PGC- $1 \alpha$ protein was consistently reduced in all types and sites of adipose tissue of obese mice. The mRNA expression of PGC-1 $\alpha$ was reduced in both visceral and subcutaneous fat (Fig. 2e and f) but was unchanged in the brown adipose tissue (Fig. 2g) of obese mice. Differently of obese humans, obese mice presented increased expression of A20 protein only in the subcutaneous fat depot, while in visceral and brown adipose tissue the expression of A20 was similar between lean and obese animals (Fig. 3a-d). Regarding mRNA levels, A20 expression in obese mice was unchanged in visceral fat, reduced in subcutaneous fat and increased in the brown adipose tissue (Fig. 3e-g). The association of PGC-1 $\alpha$ with ubiquitin was differently regulated when comparing the distinct types and sites of adipose tissue, while in subcutaneous fat and brown adipose tissue the association was reduced, in visceral fat it was increased (Fig. 4a-d). The association of PGC- $1 \alpha$ with
Table 2 Anthropometric and biochemical parameters of subjects

\begin{tabular}{lll}
\hline Parameters & Lean & Obese \\
\hline Number & 9 & 12 \\
Gender (F/M) & $8 / 1$ & $8 / 4$ \\
Age & $32 \pm 4$ & $38 \pm 6$ \\
BMl $\left(\mathrm{kg} / \mathrm{m}^{2}\right)$ & $22 \pm 2$ & $36 \pm 3^{*}$ \\
Glucose $(\mathrm{mg} / \mathrm{dL})$ & $77 \pm 7$ & $80 \pm 7$ \\
HbA1c $(\%)$ & $5.3 \pm 0.4$ & $5.4 \pm 0.3$ \\
Total Cholesterol $(\mathrm{mg} / \mathrm{dL})$ & $193 \pm 29$ & $165 \pm 17$ \\
\hline
\end{tabular}

Data are presented as means \pm standard deviation

$B M I$ body mass index, HbA1c glycated hemoglobin

A20 was also differentially regulated among the distinct types and sites of adipose tissue. Thus, it was increased in the subcutaneous fat, while unchanged in visceral fat and brown adipose tissue (Fig. 4e-h).

\section{Evaluation of PGC-1a co-expression with ubiquitin and A20 by immunofluorescence staining}

The changes in association between PGC- $1 \alpha$ and ubiquitin or A20 detected by the co-immunoprecipitation assays were mostly confirmed by immunofluorescence staining. Thus, in obese mice there was a clear increase in the co-localization of PGC- $1 \alpha$ with ubiquitin in visceral fat (Fig. 5a), while reductions were detected in brown adipose tissue and subcutaneous fat (Fig. 5a). The association of PGC- $1 \alpha$ with A20 was increased in subcutaneous fat while no major changes were detected in brown adipose tissue and visceral fat (Fig. 5b). a

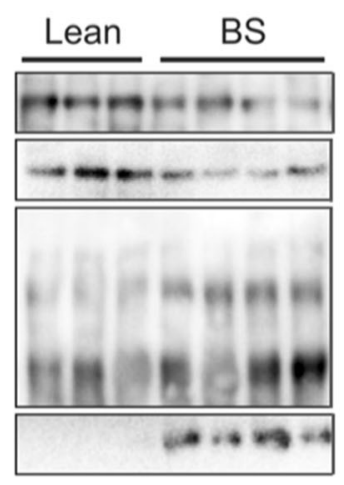

PGC1 $\alpha$

A20

PGC1 $\alpha /$ Ubi

PGC1 $/ / A 20$ b PGC1 $\alpha$

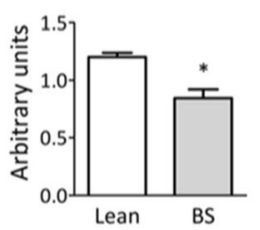

c $\mathrm{A} 20$

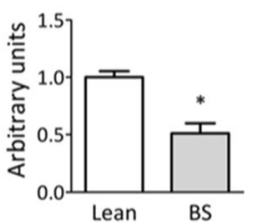

d PGC1 $\alpha /$ Ubi

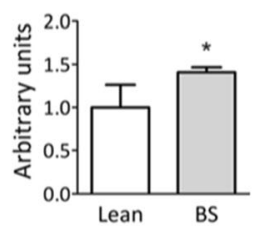

e PGC1 $\alpha / A 20$

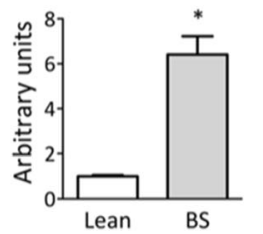

Fig. 1 PGC-1a and A20 expression in the adipose tissue of humans. Samples containing $500 \mu \mathrm{g}$ total protein from abdominal subcutaneous adipose tissue specimens, collected from 9 lean volunteers and 12 obese subjects during a Roux-in-Y gastric bypass (BS) were used in immunoprecipitation experiments employing anti-PGC-1 a (a, b, d and $\mathbf{e}$ ) or anti-A20 (a and $\mathbf{c}$ ) as primary antibodies. The immunoprecipitation procedure used antibodies sufficient to immunodeplete the sample. The immunoprecipitates were separated by SDS-PAGE, transferred to nitrocellulose membranes and blotted with anti-PGC-1 $\mathbf{a}(\mathbf{a}$ and $\mathbf{b}$ ), anti-A20 (a, $\mathbf{c}$ and $\mathbf{e}$ ) or anti-ubiquitin ( $\mathbf{a}$ and $\mathbf{d}$ ) antibodies. In A, typical blots are depicted; in B-E the quantification of bands is graphically represented. ${ }^{*} p<0.05$ vs. lean 


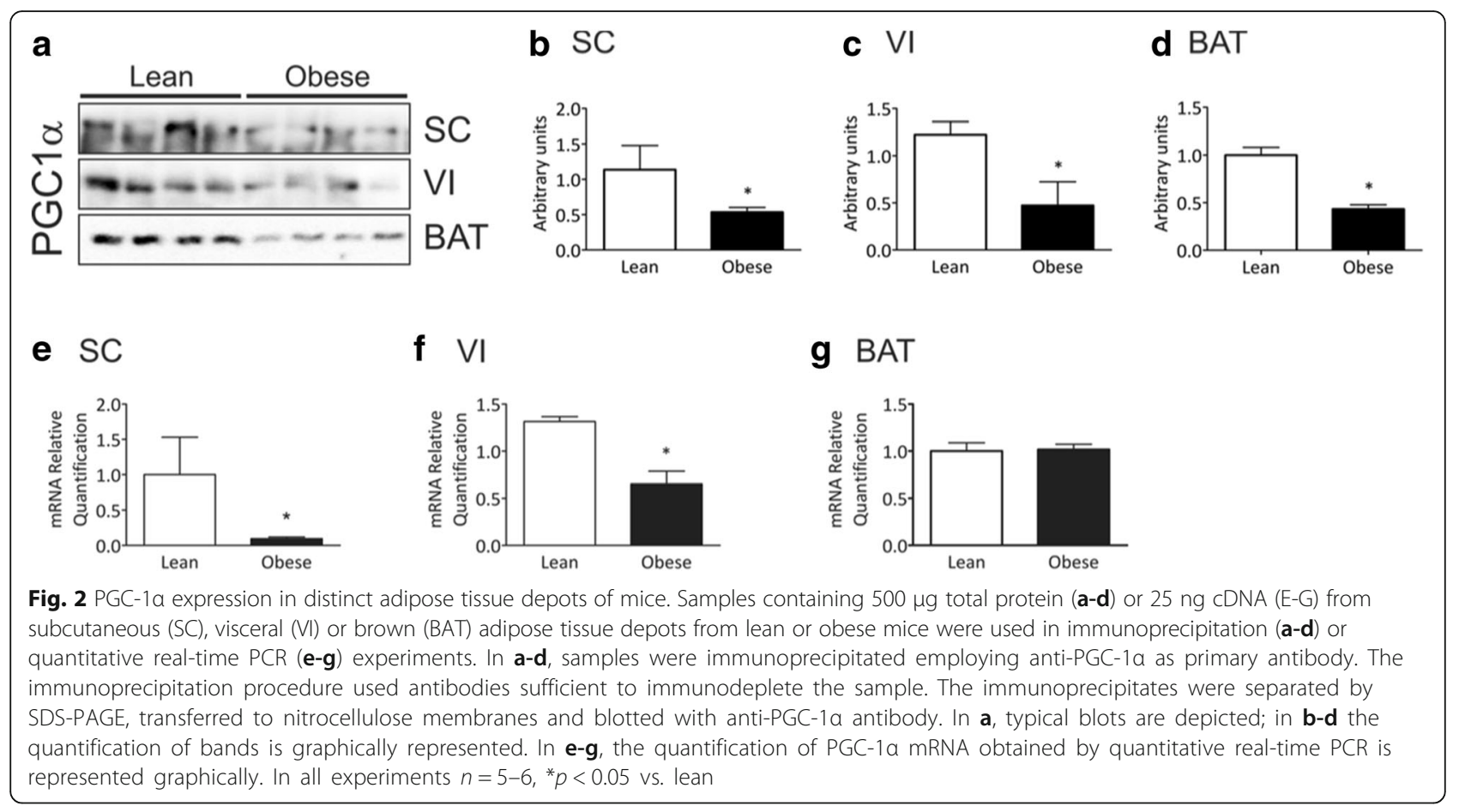

\section{Inhibition of A20 impairs whole body glucose homeostasis}

To test the hypothesis that A20 controls the levels of PGC- $1 \alpha$ which could potentially impact on the control of glucose homeostasis, we treated obese mice with an antisense oligonucleotide (ASO) against A20 and evaluated the expression of related proteins and whole body energy homeostasis. A dose-response experiment showed that the treatment with $1.0,2.0$ or $4.0 \mathrm{nmol}$ ASO per day for 7 days were sufficient to reduce the expression of either A20 or PGC- $1 \alpha$ in the subcutaneous adipose tissue (Fig. $6 \mathrm{a}$ and b). The dose of $2.0 \mathrm{nmol} /$ day was used in the remaining experiments. The intraperitoneal treatment with the A20 ASO resulted in significant reduction of A20 only in the subcutaneous fat (Fig. 6b). In brown adipose tissue and visceral fat, no changes in

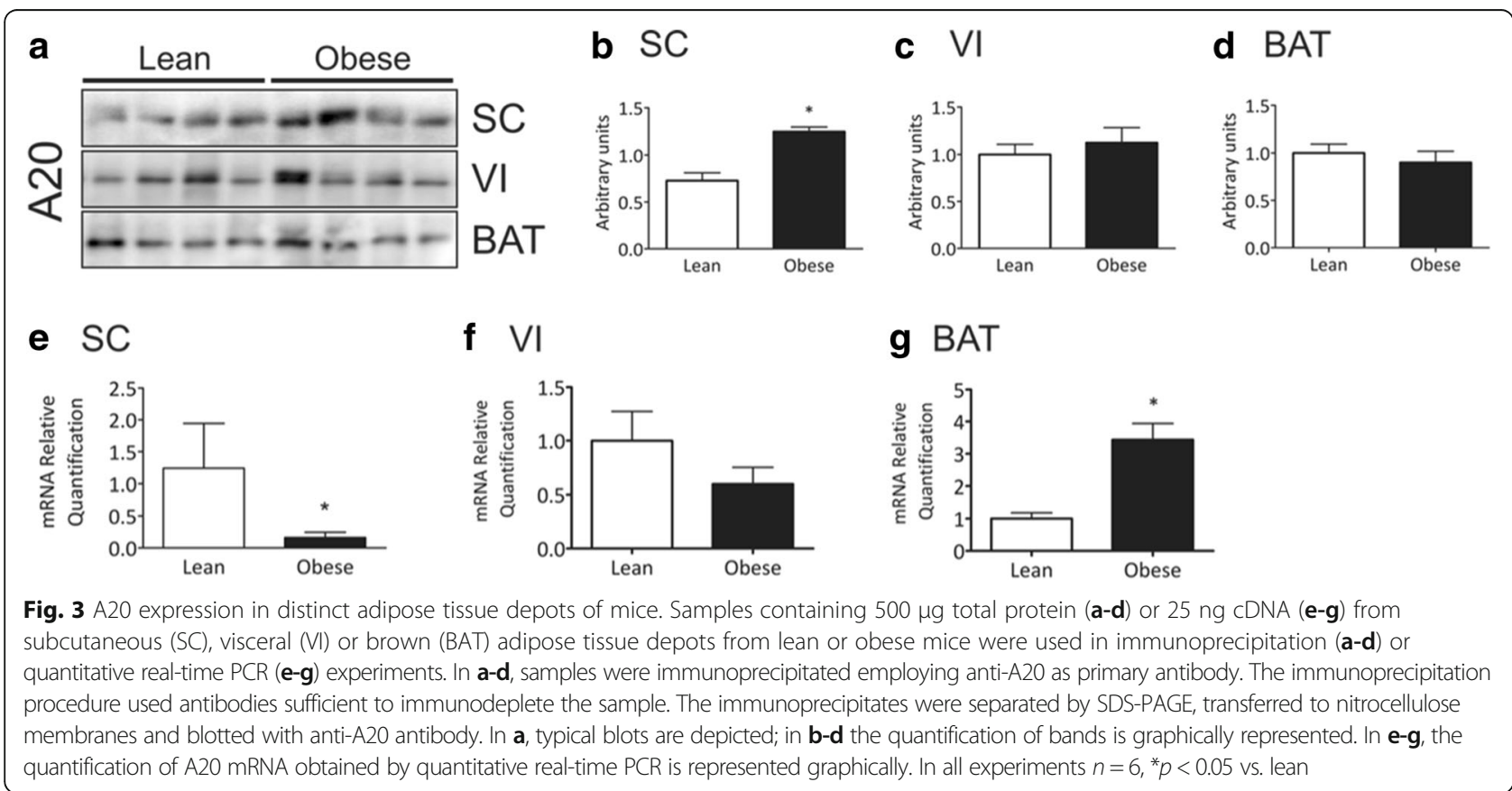




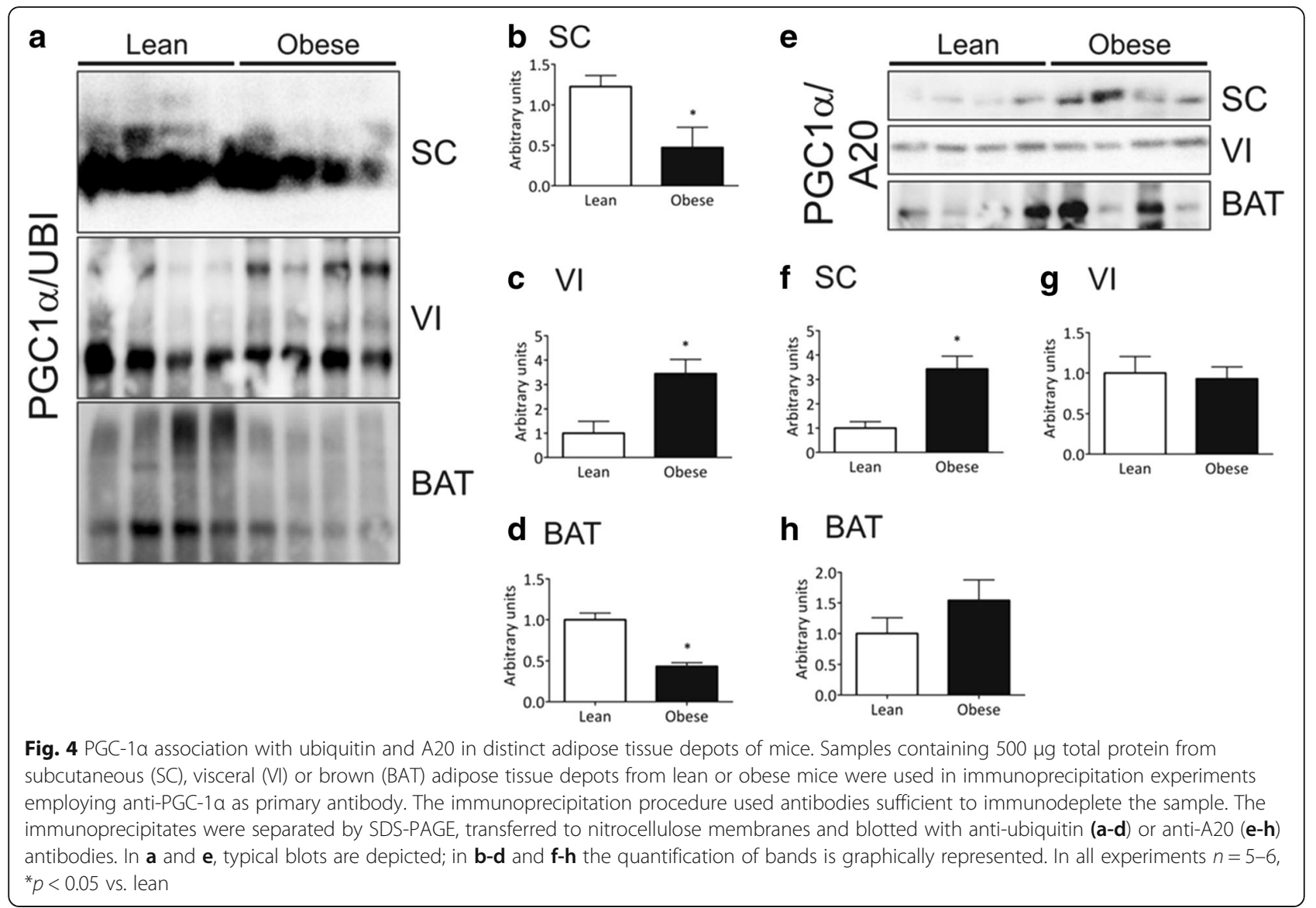

A20 levels were detected following A20 ASO treatment (Fig. 6e and h). The expressions of PGC-1 $\alpha$ and PPAR $\gamma$ were reduced only in the subcutaneous fat (Fig. 6c and d), while no changes were detected in brown adipose tissue and visceral fat (Fig. 6f/i and g/j). The inhibition of A20 resulted in no changes in food intake and body mass (not shown). However, fasting glucose levels (Fig. 6k) and the area under glucose curve during a glucose tolerance test were severely worsened by the treatment with the A20 ASO (Fig. 6l).

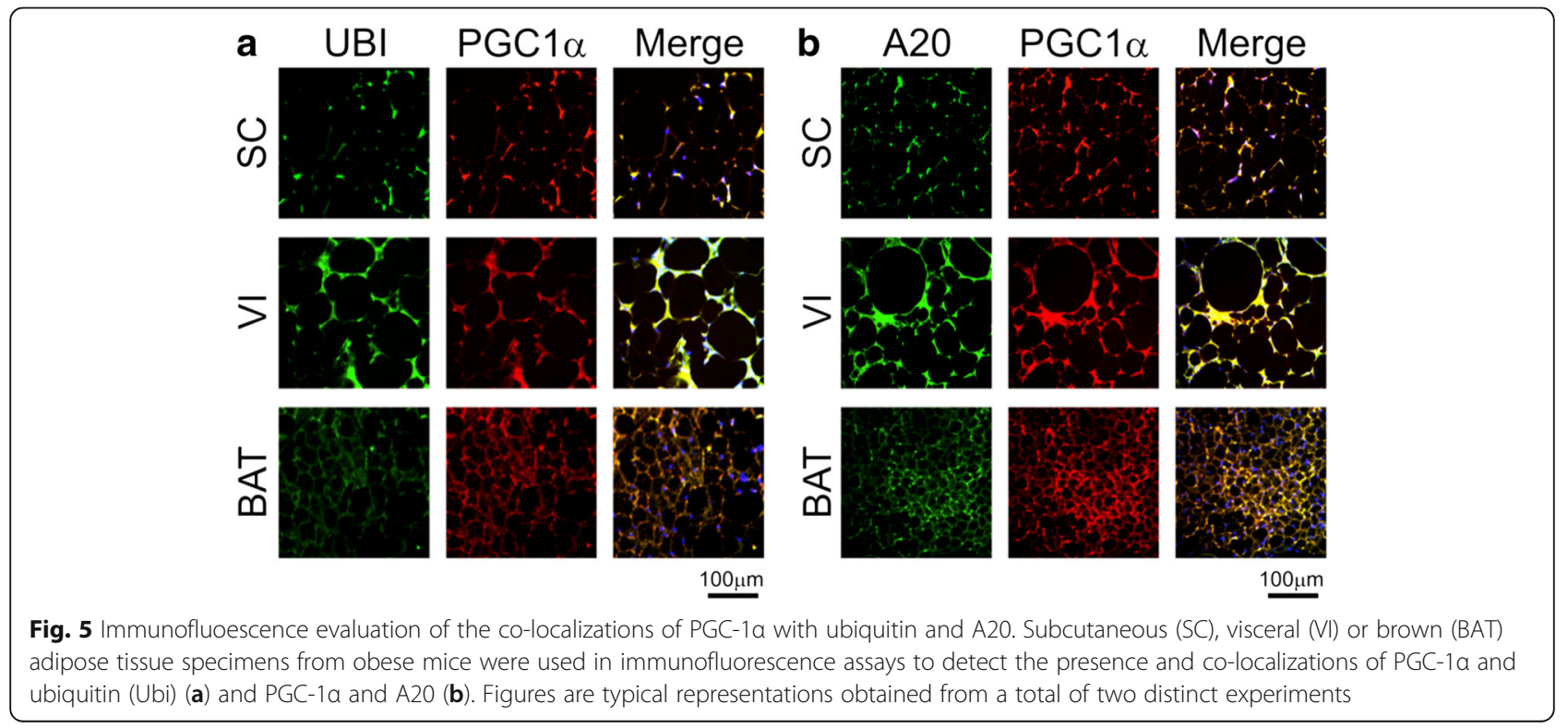




\section{Discussion}

In this study we demonstrate that PGC- $1 \alpha$ associates with A20 in the adipose tissue of humans and mice. This association is independently regulated in distinct types and sites of the adipose tissue, and increases in obesity. In all conditions analyzed in both humans and mice, the expression of adipose tissue PGC- $1 \alpha$ was reduced during obesity. In most conditions, particularly in the subcutaneous fat, the expression of PGC- $1 \alpha$ was inversely correlated with its physical association with A20, thus, raising the question of whether A20 acts to protect or to enhance PGC- $1 \alpha$ degradation.

A20 is a zinc finger protein identified as a regulator of $N F \kappa B$ activity in response to TNF $\alpha$ [27]. It has a dual role, acting as a deubiquitinase due to the catalytic activity of its N-terminal region; and, as an E3 ligase due to its $\mathrm{C}$-terminal region containing the zing finger domain $[28,29]$. The regulation of $N_{F} B$ activity is the most extensively studied function of A20. It is currently known that upon TNF $\alpha$ signal transduction through TNFR1, A20 removes the polyubiquitinated lysine- 63 residues of receptor-interacting protein-1 (RIP1) preventing its interaction with NEMO [30]. In addition, A20 adds a lysine-48 polyubiquitinated tail to RIP1, triggering its proteasome-mediated degradation [31]. These combined catalytic actions result in the inhibition of NFKB activity, and thus, attenuation of inflammation. Therefore, A20 exerts an important function in the control of NFkBdependent inflammatory signaling.

Subclinical inflammation is a common feature of human and experimental obesity $[23,32]$. Activation of TLR4 signal transduction and induction of endoplasmic reticulum stress (ERS), are regarded as two of the most important mechanisms triggering the inflammatory activity related to obesity [23, 32-34]. Once active, both TLR4 signaling and ERS induce intracellular inflammatory signal transduction through at least two important signaling intermediaries, JNK and NFKB [35-37]. As a consequence of the activation of inflammatory regulated serine-threonine kinases such as JNK, IKK the insulin receptor and some of its important primary substrates are negatively modulated by serine phosphorylation resulting in the impairment of the insulin signal transduction $[37,38]$. There are a number of cell specific outcomes resulting from inflammationinduced insulin resistance. In the adipose tissue, one such outcome is the defective activation of PPAR $\gamma$ which leads to an anomalous distribution of fat and increased expression of inflammatory adipokines, further enhancing inflammation and insulin resistance; thus, creating a vicious cycle $[24,39]$.

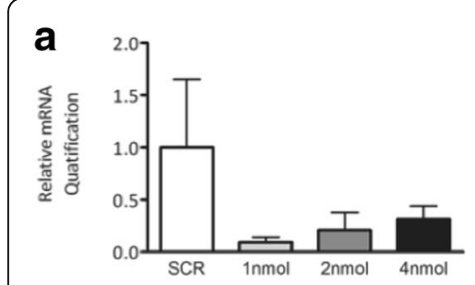

\section{b $\mathrm{A} 20$ in $\mathrm{SC}$}

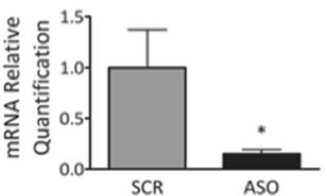

f PGC1 $\alpha$ in VI

e $A 20$ in VI

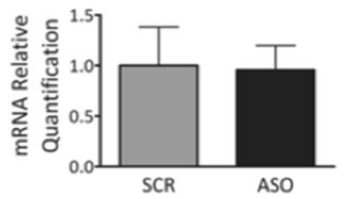

i PGC1 $\alpha$ in BAT

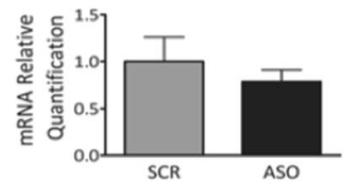

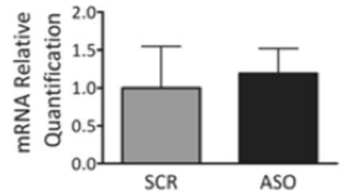

j PPARY in BAT

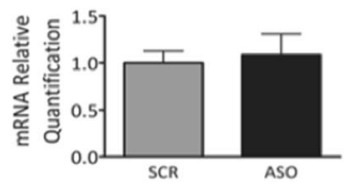

c PGC1 $\alpha$ in SC

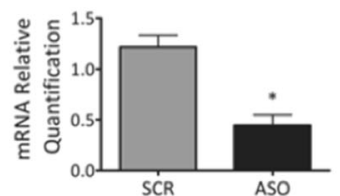

g PPARy in VI
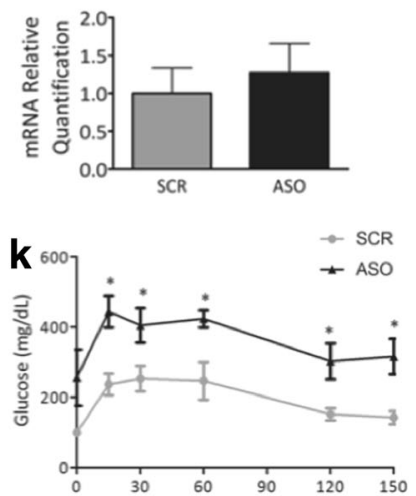

d PPARY in SC

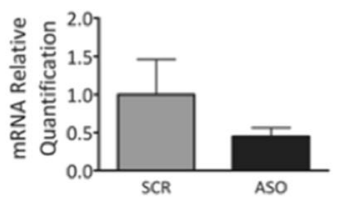

h A20 in BAT

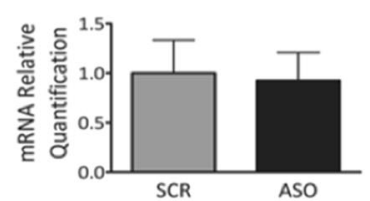

I

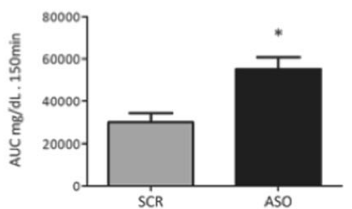

Fig. 6 Inhibiting A20 expression. Obese Swiss mice were treated once a day, for 7 days, with a single intraperitoneal injection of a 100 $\mu$ l solution containing either A20 antisense (ASO) or scrambled (SCR) oligonucleotide. Fragments from subcutaneous (SC) (a-d), visceral (VI) (e-g) or brown (BAT) (h-j) adipose tissue were employed in quantitative real-time PCR experiments. In a, A20 transcript expression was evaluated in a dose-response experiment to determine the efficiency of the method. In $\mathbf{b}-\mathbf{I}$, the doses of ASO and SCR employed were always 2 nmol in $100 \mu \mathrm{l} /$ dose. In $\mathbf{b}-\mathbf{j}$, the expressions of A20 (b, e, h); PGC-1a (c, f, i); and PPARY $(\mathbf{d}, \mathbf{g}$, j) were determined and are represented graphically. The blood glucose levels during a glucose tolerance test $(\mathbf{k})$ and the respective area under the glucose curve (I) are represented graphically. In all experiments $n$ $=8 ;{ }^{*} p<0.05$ vs. SCR 
Because PGC-1 $\alpha$ is an important regulator of PPAR $\gamma$ expression we asked whether in obesity the expression of PGC- $1 \alpha$ would be reduced, and, if so, what would be the role of A20 in this context. First, we showed that in both obese humans and mice the expression of PGC-1 $\alpha$ was indeed reduced. In the case of mice, this was occurring in visceral and subcutaneous fat and also in BAT. These findings confirm previous studies that evaluated PGC- $1 \alpha$ in different groups of obese subjects and showed a consistent reduction in both visceral and subcutaneous depots [40-42].

Next, to test our working hypothesis, we determined the levels of $\mathrm{A} 20$ and its interaction with PGC-1 $\alpha$. In both humans and mice, in the subcutaneous fat, A20/PGC- $1 \alpha$ association was increased, while in mice visceral fat and BAT it was unchanged. No previous study has evaluated the association of PGC$1 \alpha$ with A20. However, in other studies, the activity of A20 related to its ability to bind to distinct proteins resulted, in most times, in the modification of the target protein expression levels [28, 30, 31, 43].

A20 can act to modify a given target protein expression by at least two mechanisms, deubiquitination and/ or E3 ligase activity $[28,30]$. Although we have not evaluated the potential involvement of the distinct functions of A20 to control PGC- $1 \alpha$ expression, we employed a method to reduce A20 expression and looked for the outcome on PGC- $1 \alpha$ levels and modulation of metabolic functions. Interestingly, the use of an ASO targeting A20 resulted in the reduction of A20 expression only in the subcutaneous fat depot, while no changes were detected in the visceral fat and BAT. The reason for this apparent specificity was not investigated but it is currently known that mRNA targeting with ASOs or even siRNA approaches can result in reduction, no modulation or even increase of the target expression [44-46]. This can be due to factors such as, for example, differences in the uptake of the oligonucleotide or the presence of endogenous siRNAs.

In the subcutaneous adipose tissue, the reduction of A20 was accompanied by a reduction of PGC- $1 \alpha$ and PPAR $\gamma$, while in the other two adipose sites no changes in the expression of PGC- $1 \alpha$ and PPAR $\gamma$ were detected. As an outcome of A20 inhibition there was an increase in fasting glucose levels and in the area under glucose curve during a glucose tolerance test, which were independent on changes in caloric intake and body mass. In a number of different contexts the reductions in the expression of either PGC- $1 \alpha$ or PPAR $\gamma$ in the adipose tissue have been shown to result in impaired glucose tolerance [47-49]. Thus, the role of A20 controlling subcutaneous adipose tissue levels of PGC- $1 \alpha$ impacts on PPAR $\gamma$ levels resulting in an important change in whole body glucose homeostasis.

\section{Conclusion}

This study has shown that in distinct sites of the adipose tissue A20 binds to PGC- $1 \alpha$. At least in the subcutaneous fat of humans and mice the levels of PGC- $1 \alpha$ decrease during obesity, while its physical association with A20 increases. The inhibition of A20 in this site produces a reduction of PGC- $1 \alpha$ and PPAR $\gamma$ expression, suggesting that A20 acts as a protective factor against PGC- $1 \alpha$ disposal. Thus, we provide additional [16] evidence that mechanisms regulating PGC- $1 \alpha$ ubiquitination are potentially involved in the control of the function of this transcriptional co-activator.

\section{Abbreviations}

BAT: Brown adipose tissue; CREB: CAMP Response Element-Binding protein; IKK: IKB Kinase; JNK: c-Jun N-terminal Kinase; MAPK: Mitogen-activated protein kinases; MEF: Myocyte enhancer factor; NFkB: Nuclear Factor-KappaB; PGC1a: Peroxisome proliferator-activated receptor gamma coactivator 1alpha; PPARY: Peroxisome proliferator-activated receptor gamma; RIP1: Receptor-interacting protein-1; TNFa: Tumor necrosis factor alpha; UCP1: Uncoupling protein-1; WAT: White adipose tissue

\section{Acknowledgements}

We thank Dr. E. Roman, Mr. J. G. Ferraz and Mr. M. Cruz, from the University of Campinas, for assistance with the experiments. We thank Dr. N. Conran, from the University of Campinas, for editing the English grammar. The authors belong to the Obesity and Comorbidities Research Center.

\section{Funding}

The grants were provided by Sao Paulo Research Foundation and Conselho Nacional de Desenvolvimento Científico e Tecnológico.

Availability of data and materials

Upon request authors will make available all data produced in this study.

\section{Authors' contributions}

BB and LAV designed the study; BB, LMI-S, CEN, DSR, RMP and AC performed the experiments; EAC recruited, selected and followed up patients; EPA and EAC contributed to discussions; BB ad LAV wrote manuscript. All authors reviewed the manuscript. All authors read and approved the final manuscript.

\section{Ethics approval and consent to participate}

The human part of the study was approved by the University of Campinas Ethics Committee for Medical Research (\#833/2010). The experimental part of the study were performed in accordance with the guidelines of the Brazilian College for Animal Experimentation and were approved by the University of Campinas Ethics Committee (\#CEUA 2216-1).

\section{Consent for publication}

All authors agree with this publication,

\section{Competing interests}

The authors declare that they have no competing interests.

\section{Publisher's Note}

Springer Nature remains neutral with regard to jurisdictional claims in published maps and institutional affiliations.

\section{Author details}

'Laboratory of Cell Signaling, Obesity and Comorbidities Research Center University of Campinas, Campinas, Brazil. ${ }^{2}$ Department of Surgery, University of Campinas, Campinas, Brazil. ${ }^{3}$ Laboratory of Cell Signaling, Faculdade de Ciencias Medicas da Universidade Estadual de Campinas, Campinas, SP 13084 970, Brazil. 


\section{Received: 4 October 2017 Accepted: 9 April 2018} Published online: 20 April 2018

\section{References}

1. Handschin C, Spiegelman BM. Peroxisome proliferator-activated receptor gamma coactivator 1 coactivators, energy homeostasis, and metabolism. Endocr Rev. 2006;27:728-35.

2. Fuentes E, Guzman-Jofre L, Moore-Carrasco R, Palomo I. Role of PPARs in inflammatory processes associated with metabolic syndrome (review). Mol Med Rep. 2013;8:1611-6.

3. Puigserver P, Wu Z, Park CW, Graves R, Wright M, Spiegelman BM. A coldinducible coactivator of nuclear receptors linked to adaptive thermogenesis. Cell. 1998;92:829-39.

4. Bargut TCL, Souza-Mello V, Aguila MB, Mandarim-de-Lacerda CA: Browning of white adipose tissue: lessons from experimental models. Horm Mol Biol Clin Investig 2017;31:1-13.

5. De Souza CT, Gasparetti AL, Pereira-da-Silva M, Araujo EP, Carvalheira JB, Saad MJ, Boschero AC, Carneiro EM, Velloso LA. Peroxisome proliferatoractivated receptor gamma coactivator-1-dependent uncoupling protein-2 expression in pancreatic islets of rats: a novel pathway for neural control of insulin secretion. Diabetologia. 2003;46:1522-31.

6. Zhang Y, Guo H, Deis JA, Mashek MG, Zhao M, Ariyakumar D, Armien AG, Bernlohr DA, Mashek DG, Chen X. Lipocalin 2 regulates brown fat activation via a nonadrenergic activation mechanism. J Biol Chem. 2014;289:22063-77.

7. Lin J, Wu H, Tarr PT, Zhang CY, Wu Z, Boss O, Michael LF, Puigserver P,

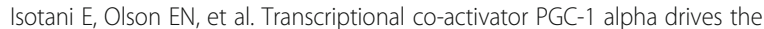
formation of slow-twitch muscle fibres. Nature. 2002;418:797-801.

8. Nakamura MT, Yudell BE, Loor JJ. Regulation of energy metabolism by longchain fatty acids. Prog Lipid Res. 2014;53:124-44.

9. Yoon JC, Puigserver P, Chen G, Donovan J, Wu Z, Rhee J, Adelmant G, Stafford J, Kahn CR, Granner DK, et al. Control of hepatic gluconeogenesis through the transcriptional coactivator PGC-1. Nature. 2001;413:131-8.

10. Herzig S, Long F, Jhala US, Hedrick S, Quinn R, Bauer A, Rudolph D, Schutz $G$, Yoon C, Puigserver $P$, et al. CREB regulates hepatic gluconeogenesis through the coactivator PGC-1. Nature. 2001;413:179-83.

11. Handschin C, Rhee J, Lin J, Tarr PT, Spiegelman BM. An autoregulatory loop controls peroxisome proliferator-activated receptor gamma coactivator 1alpha expression in muscle. Proc Natl Acad Sci U S A. 2003;100:7111-6.

12. Nisoli E, Clementi E, Paolucci C, Cozzi V, Tonello C, Sciorati C, Bracale R, Valerio A, Francolini M, Moncada S, Carruba MO. Mitochondrial biogenesis in mammals: the role of endogenous nitric oxide. Science. 2003;299:896-9.

13. Hondares E, Mora O, Yubero P, Rodriguez de la Concepcion M, Iglesias R, Giralt M, Villarroya F. Thiazolidinediones and rexinoids induce peroxisome proliferator-activated receptor-coactivator (PGC)-1alpha gene transcription: an autoregulatory loop controls PGC-1alpha expression in adipocytes via peroxisome proliferator-activated receptor-gamma coactivation. Endocrinology. 2006;147:2829-38.

14. Puigserver P, Rhee J, Lin J, Wu Z, Yoon JC, Zhang CY, Krauss S, Mootha VK Lowell BB, Spiegelman BM. Cytokine stimulation of energy expenditure through p38 MAP kinase activation of PPARgamma coactivator-1. Mol Cell. 2001;8:971-82

15. Knutti D, Kressler D, Kralli A. Regulation of the transcriptional coactivator PGC-1 via MAPK-sensitive interaction with a repressor. Proc Natl Acad Sci U S A. 2001;98:9713-8

16. Sano M, Tokudome S, Shimizu N, Yoshikawa N, Ogawa C, Shirakawa K, Endo J, Katayama T, Yuasa S, leda M, et al. Intramolecular control of protein stability, subnuclear compartmentalization, and coactivator function of peroxisome proliferator-activated receptor gamma coactivator 1alpha. J Biol Chem. 2007:282:25970-80.

17. Trausch-Azar J, Leone TC, Kelly DP, Schwartz AL. Ubiquitin proteasomedependent degradation of the transcriptional coactivator PGC-1a via the Nterminal pathway. J Biol Chem. 2010;285:40192-200.

18. Welchman RL, Gordon C, Mayer RJ. Ubiquitin and ubiquitin-like proteins as multifunctional signals. Nat Rev Mol Cell Biol. 2005;6:599-609.

19. Kattah MG, Malynn BA, Ma A. Ubiquitin-modifying enzymes and regulation of the Inflammasome. J Mol Biol. 2017:429:3471-85.

20. Kirkin V, McEwan DG, Novak I, Dikic I. A role for ubiquitin in selective autophagy. Mol Cell. 2009;34:259-69.

21. Sun D, Wu R, Zheng J, Li P, Yu L: Polyubiquitin chain-induced p62 phase separation drives autophagic cargo segregation. Cell Res. 2018. https://doi. org/10.1038/s41422-018-0017-7
22. Leotoing L, Chereau F, Baron S, Hube F, Valencia HJ, Bordereaux D, Demmers JA, Strouboulis J, Baud V. A20-binding inhibitor of nuclear factorkappaB (NF-kappaB)-2 (ABIN-2) is an activator of inhibitor of NF-kappaB (IkappaB) kinase alpha (IKKalpha)-mediated NF-kappaB transcriptional activity. J Biol Chem. 2011;286:32277-88.

23. Gregor MF, Hotamisligil GS. Inflammatory mechanisms in obesity. Annu Rev Immunol. 2011;29:415-45.

24. Sharma AM, Staels B. Review: peroxisome proliferator-activated receptor gamma and adipose tissue-understanding obesity-related changes in regulation of lipid and glucose metabolism. J Clin Endocrinol Metab. 2007; 92:386-95.

25. Gupta N, Fisker N, Asselin MC, Lindholm M, Rosenbohm C, Orum H, Elmen J, Seidah NG, Straarup EM. A locked nucleic acid antisense oligonucleotide (LNA) silences PCSK9 and enhances LDLR expression in vitro and in vivo. PLoS One. 2010;5:e10682.

26. Lundbaek K. Intravenous glucose tolerance as a tool in definition and diagnosis of diabetes mellitus. Br Med J. 1962;1:1507-13.

27. Coornaert B, Carpentier I, Beyaert R. A20: central gatekeeper in inflammation and immunity. J Biol Chem. 2009;284:8217-21.

28. Wertz IE, O'Rourke KM, Zhou H, Eby M, Aravind L, Seshagiri S, Wu P, Wiesmann C, Baker R, Boone DL, et al. De-ubiquitination and ubiquitin ligase domains of A20 downregulate NF-kappaB signalling. Nature. 2004; 430:694-9.

29. Verstrepen L, Verhelst K, van Loo G, Carpentier I, Ley SC, Beyaert R. Expression, biological activities and mechanisms of action of A20 (TNFAIP3). Biochem Pharmacol. 2010;80:2009-20.

30. Bertrand MJ, Milutinovic S, Dickson KM, Ho WC, Boudreault A, Durkin J, Gillard JW, Jaquith JB, Morris SJ, Barker PA. CIAP1 and CIAP2 facilitate cancer cell survival by functioning as E3 ligases that promote RIP1 ubiquitination. Mol Cell. 2008:30:689-700.

31. Newton K, Matsumoto ML, Wertz IE, Kirkpatrick DS, Lill JR, Tan J, Dugger D, Gordon N, Sidhu SS, Fellouse FA, et al. Ubiquitin chain editing revealed by polyubiquitin linkage-specific antibodies. Cell. 2008;134:668-78.

32. Cnop M, Foufelle F, Velloso LA. Endoplasmic reticulum stress, obesity and diabetes. Trends Mol Med. 2012;18:59-68.

33. Velloso LA, Folli F, Saad MJ. TLR4 at the crossroads of nutrients, gut microbiota, and metabolic inflammation. Endocr Rev. 2015;36:245-71.

34. Nunez CE, Rodrigues VS, Gomes FS, Moura RF, Victorio SC, Bombassaro B, Chaim EA, Pareja JC, Geloneze B, Velloso LA, Araujo EP. Defective regulation of adipose tissue autophagy in obesity. Int J Obes. 2013;37:1473-80.

35. Tsukumo DM, Carvalho-Filho MA, Carvalheira JB, Prada PO, Hirabara SM, Schenka AA, Araujo EP, Vassallo J, Curi R, Velloso LA, Saad MJ. Loss-offunction mutation in toll-like receptor 4 prevents diet-induced obesity and insulin resistance. Diabetes. 2007;56:1986-98.

36. Ozcan U, Cao Q, Yilmaz E, Lee AH, Iwakoshi NN, Ozdelen E, Tuncman G, Gorgun C, Glimcher LH, Hotamisligil GS. Endoplasmic reticulum stress links obesity, insulin action, and type 2 diabetes. Science. 2004:306:457-61.

37. Cai D, Yuan M, Frantz DF, Melendez PA, Hansen L, Lee J, Shoelson SE. Local and systemic insulin resistance resulting from hepatic activation of IKK-beta and NF-kappaB. Nat Med. 2005;11:183-90.

38. Hirosumi J, Tuncman G, Chang L, Gorgun CZ, Uysal KT, Maeda K, Karin M, Hotamisligil GS. A central role for JNK in obesity and insulin resistance. Nature. 2002;420:333-6.

39. Kim JY, van de Wall E, Laplante M, Azzara A, Trujillo ME, Hofmann SM, Schraw T, Durand JL, Li H, Li G, et al. Obesity-associated improvements in metabolic profile through expansion of adipose tissue. J Clin Invest. 2007; 117:2621-37.

40. Semple RK, Crowley VC, Sewter CP, Laudes M, Christodoulides C, Considine RV, Vidal-Puig A, O'Rahilly S. Expression of the thermogenic nuclear hormone receptor coactivator PGC-1alpha is reduced in the adipose tissue of morbidly obese subjects. Int J Obes Relat Metab Disord. 2004;28:176-9.

41. Ruschke K, Fishbein L, Dietrich A, Kloting N, Tonjes A, Oberbach A, Fasshauer M, Jenkner J, Schon MR, Stumvoll M, et al. Gene expression of PPARgamma and PGC-1alpha in human omental and subcutaneous adipose tissues is related to insulin resistance markers and mediates beneficial effects of physical training. Eur J Endocrinol. 2010;162:515-23.

42. Moreno-Santos I, Perez-Belmonte LM, Macias-Gonzalez M, Mataro MJ, Castellano D, Lopez-Garrido M, Porras-Martin C, Sanchez-Fernandez PL, Gomez-Doblas JJ, Cardona F, et al. Type 2 diabetes is associated with decreased PGC1alpha expression in epicardial adipose tissue of patients with coronary artery disease. J Transl Med. 2016;14:243. 
43. Boone DL, Turer EE, Lee EG, Ahmad RC, Wheeler MT, Tsui C, Hurley P, Chien $\mathrm{M}$, Chai S, Hitotsumatsu $\mathrm{O}$, et al. The ubiquitin-modifying enzyme A20 is required for termination of toll-like receptor responses. Nat Immunol. 2004; 5:1052-60.

44. Dias N, Stein CA. Antisense oligonucleotides: basic concepts and mechanisms. Mol Cancer Ther. 2002;1:347-55.

45. Wheeler TM, Sobczak K, Lueck JD, Osborne RJ, Lin X, Dirksen RT, Thornton CA. Reversal of RNA dominance by displacement of protein sequestered on triplet repeat RNA. Science. 2009;325:336-9.

46. Castanotto D, Rossi JJ. The promises and pitfalls of RNA-interference-based therapeutics. Nature. 2009:457:426-33.

47. He W, Barak Y, Hevener A, Olson P, Liao D, Le J, Nelson M, Ong E, Olefsky $J M$, Evans RM. Adipose-specific peroxisome proliferator-activated receptor gamma knockout causes insulin resistance in fat and liver but not in muscle. Proc Natl Acad Sci U S A. 2003:100:15712-7.

48. Olswang Y, Cohen H, Papo O, Cassuto H, Croniger CM, Hakimi P, Tilghman $S M$, Hanson RW, Reshef L. A mutation in the peroxisome proliferatoractivated receptor gamma-binding site in the gene for the cytosolic form of phosphoenolpyruvate carboxykinase reduces adipose tissue size and fat content in mice. Proc Natl Acad Sci U S A. 2002;99:625-30.

49. Kleiner S, Mepani RJ, Laznik D, Ye L, Jurczak MJ, Jornayvaz FR, Estall JL, Chatterjee Bhowmick D, Shulman Gl, Spiegelman BM. Development of insulin resistance in mice lacking PGC-1alpha in adipose tissues. Proc Natl Acad Sci U S A. 2012;109:9635-40.

Ready to submit your research? Choose BMC and benefit from:

- fast, convenient online submission

- thorough peer review by experienced researchers in your field

- rapid publication on acceptance

- support for research data, including large and complex data types

- gold Open Access which fosters wider collaboration and increased citations

- maximum visibility for your research: over $100 \mathrm{M}$ website views per year

At BMC, research is always in progress.

Learn more biomedcentral.com/submissions 